\title{
IBN SINA'S THEORY OF THE SOUL: A TAXONOMY OF ISLAMIC EDUCATION
}

\author{
Nurul Ain Norman*
}

\begin{abstract}
Ibn Sina's theory of the soul possesses a logical-metaphysical categorisation of that concept, which allows for the designing of a new taxonomy of educational objectives. Its unique alteration of Aristotelian philosophy creates both an understanding of the natural relationship between categories, species, varieties, etc., and powerful inventive philosophical arguments and principles supporting the structural basis of monotheistic belief (tawhid). When speaking of the goals and objectives of the contemporary Islamic educational world, this approach also embraces the demands of the twenty-first century knowledge economy and the holistic development of the human being, enabling people to become critical, creative, innovative, and ethical without leaving religion behind. However, the new scene has created volatility, uncertainty, complexity, and ambiguity among educators as to how to liaise the new curriculum and apply new assessment methods in their classrooms. This study intends to develop a taxonomy that will enable curriculum designers and Islamic educators to easily identify hierarchal and categorical human faculties and relate them to specific curricular objectives, proper classroom assessments, and suitable teaching methods. The taxonomy is designed using a philosophical-descriptive analysis of Ibn Sina's theory of the soul and a logic-argumentative description of his human categorisation. The end result is a prototype taxonomy for future validity evaluation.
\end{abstract}

Keywords: taxonomy, Islamic education objectives, Ibn Sina, theory of the soul, Aristotle.

\section{Introduction}

The Holy Qur'an repeatedly invites man to think and reason, using words such as nazar (observe), tafakkur (think), and tadabbur (reflect). The spiritual act of thinking and reasoning is considered a sign of devotion and intellectuality, and will be reflected in the faith (iman) and acts ('amal) of a Muslim. There are about 750 verses in the Qur' an exhorting readers to study nat ure, humanity, and history, including 10:101: "Say, 'Observe what is in the heavens and the earth."' Within this context, logic has an epistemic way of defining rationality. The definition of 
man is extracted from the logical categorisation of existence, including nature's species, genera, and differentiae, resulting in a distinct criterion that explores the essence of the subject matter. "Man", referring to "what-it-is" in logic, defines the term "Rational Animal" (genus: animal, differentia: rational) and is seen as inseparable from the man himself. Thus, it is possible to say that "rationality" is man's essence, or a blended attribution thereof, and that it cannot be seen as new jargon related to a particular group or nation.

One of the most important and influential figures in global intellectual history is Ibn Sina (c. 980-1037), who developed a theory of the soul that classified its nat ure in a systematic, logical-metaphysical way, arranging concepts and elements according to the structure of monotheistic belief (tawhid). He used unique properties and harmonic proportions to reconcile his theory with al-Farabi's concept of the soul, ${ }^{2}$ thereby separating it from the fundamental principles of Aristotle's framework. It signifies a two-fold causal chain, one facing the world of physics - bringing about the perspective of perfection through a microcosmic lens - and the other facing the world of metaphysics - perceiving man from a macrocosmic angle. Many of Ibn Sina's works have been translated into various languages, significantly impacting later traditions. The fundamental elements of his theories have been universally adopted, providing the theoretical basis for later contemporary thought.

\section{Ibn Sina's Theory of the Soul and His View of Education}

Ibn Sina conceived the unseen and observable universe as being closely related, stitching Peripatetic philosophical concepts and principles together with exceptional mystical insight, creating a beautiful embroidery of his own. His theory can be represented by a hierarchical figure, showing continuous descending movement of intelligible emanation towards the sublunary world and an ascending movement of universal forms - originated from human intellection - towards the world of the Intellects. The activation process of intellectual potency happens only through cooperative management of the soul and body and the willingness of man to engage in that process. Ibn Sina anchored elements of rationality and intellection, derived from different angles of logic and philosophy, in his world of epistemological thought.

By exploring man's natural disposition (fitrah) towards individual perfection and ultimate happiness, knowledge is seen as a holy instrument for revealing God's beauty through man's journey of self-knowledge. This expounds the meaning of the hadith: "Whosoever knows himself, knows his Lord." 
As a Peripatetic philosopher, Ibn Sina examined man using logical reasoning and deductive argument. Man as a Rational Animal (haywan al-natiq) is initially separated from the other animal species (genus) due to his possession of rationality (differentia). This concept is later classified based on the species of soul; not in the sense that the soul has several species - it is impossible for an immaterial existence to have such properties - but due to its relevance as a medium for reaching perfection. Thereby, man possesses the dual task of attaining perfection through intellection of the material world and through the perfection of the Rational Soul, which allows an emanation process to happen within that soul. When man is united with the Universal Intelligible, he is qualified to be the Perfect Man. If he only practices intellection in a way that reflects his actions, however, he is seen as an ethical man with good conduct and moral character (a man with akhlaq). If, on the other hand, a man is unwilling to practice intellection in any form, completely rejecting his potencies for self-perfection, then the outcome will be poor conduct and non-ethical characteristics. This shows that the actions of a man are ultimately the manifestation of his thoughts.

Although Ibn Sina viewed the body as subordinate to and a deflection of the soul, he held that the act of intellection purifies the body from any bad qualities that may be attached to it. The soul must work alongside and be with the bodily faculties under one principle to produce either good or immoral acts. This is where Ibn Sina's concept of soul-body relation needs to be clarified. Fazlur Rahman mentioned at the beginning of Avicenna's Psychology that Ibn Sina elaborates on the unity of body and soul as follows:

When the elements are mixed in a more harmonious way i.e. in a more balanced proportion than in the cases previously mentioned, other beings also come into existence out of them due to the powers of the heavenly bodies...It is the unitary substance of the soul that links all the powers together to govern and separate every act of every faculty. ${ }^{3}$

Ibn Sina therefore interprets soul-body unity in terms of attachment (inzimam), not essence (ittihad). ${ }^{4}$ This type of relationship is defined as accidental and does not change the essence of existence. Aristotle, on the contrary, defined the soul as a substantial form that requires the impression (intiba') of the body to actualise its potentiality. ${ }^{5}$ Another notable invention related to this discussion is Ibn Sina's Flying Man argument, which is structured around experimental thought. He mentions in al-Shifa' that:

So we say that it has to be imagined as though one of us were created whole in an instant but his sight is veiled from directly observing the things of the external world. He is created as though floating in the air 
or in a void but without the air supporting him in such a way that he would have to feel it, and the limbs of his body are stretched out and away from one another, so they do not come into contact or touch. Then he considers whether he can assert the existence of his self. He has no doubts about asserting his self as something that exists without also [having to] assert the existence of any of his exterior or interior parts, his heart, his brain, or anything external. ${ }^{6}$

Ibn Sina's categorisation of the bodily faculties is based on soul species and is a result of the mental act. The soul's essence is unperceivable by man; hence it can only be known through accidental relationships (the body's action with the human soul). It is appropriate to say that the Vegetative Soul is the genus of the Animal Soul; and that the Animal Soul is the genus of the Rational Soul. Ibn Sina asserts that when the "types of souls" are defined, the higher-posited souls (visualised in a hierarchy) should include the characteristics of lower-posited souls, e.g. vegetative connotations should be included in the Animal Soul. His comprehensive definition of the three categories of soul can be seen below: ${ }^{7}$

1. The Vegetative Soul is the primary perfection of a natural body, possessing organs in-so-far as the bodies reproduce, grow, and assimilate nourishment.

2. The Animal Soul is the primary perfection of a natural body, possessing organs in-so-far as it perceives individuals and moves by volition.

3. The Rational Soul is the primary perfection of a natural body, possessing organs in-so-far as it acts by rational choice and rational deduction, and perceives universals.

It is important to note that the word "perfection" in the above definitions does not denote the character of being free of matter (or abstracted from matter), but implies primary perfection of the three categories. This primary perfection is different from secondary perfection; the latter needs to be perfected by something other than itself, while the former does not, here referring to those particular bodily actions that perfect (or make perfect) the particular type of soul.

The first category of the human soul consists of three faculties: nutritive, growth, and reproductive. The function of these three faculties perfects the Vegetative Soul. However, suppose the bodily faculties of this soul are observed through its actions. In that case, the perfection of human development depends heavily on adequate nutrition and normal growth progression, thus revealing the reason why Ibn Sina gave plenty of attention to these factors for ensuring the proper development of children. ${ }^{8}$ 
The Animal Soul consists of two major divisions: the motion/motor and perception faculties. The motor faculty is divided into two further categories: 1) the faculty that incites other faculties to move, and 2) the faculty that produces action. The first involves the appetitive and irascible faculties, which incite animals and human beings to move closer or further away from something. The second category involves the production of movement from the interaction of the soul with the bodily organs. The perceptive faculty of the Animal Soul is related to the principle of potentiality and is divided into external and internal faculties. The external faculties include the five senses: sight, smell, taste, hearing, and touch. Visual processing, for example, starts with the introduction of various stimuli from the external senses (hiss al-mushtarak) and is brought to common sense for integration and abstraction. The retentive faculty (quwwah al-khiyaliyyah) absorbs and stores these integratedabstracted forms, which are later used by the estimative and imaginative faculties to produce action. The estimative (wahm) faculty absorbs non-sensible intentions (or connotational attributes, ma'na) from sensible objects and the imaginative (mukhayyalah) faculty recollects, combines, and separates them.

The imaginative faculty is divided into two parts, one belonging to the animals, the other only to man. The first is the sensitive-imaginative faculty, while the second is the rational-imaginative faculty. If human beings refuse to reason, they will remain as Animal Souls, reflecting only through the estimative and sensitive-imagination faculties. Ibn Sina's categorisation of the Animal Soul can be seen as follows:

\begin{tabular}{|c|c|c|}
\hline $\begin{array}{c}\text { Faculties of the Animal } \\
\text { Soul }\end{array}$ & Sub-faculties & Sub-Sub Faculties \\
\hline 1) Motor Faculty & $\begin{array}{l}\text { 1.1: Causes motion } \\
\text { 1.2: Produces motion }\end{array}$ & $\begin{array}{l}\text { 1.1.1: Appetitive faculty } \\
\text { 1.1.2: Irascible faculty }\end{array}$ \\
\hline 2) Faculty of Perception & $\begin{array}{l}\text { 2.1: Faculty of external } \\
\text { perception }\end{array}$ & $\begin{array}{l}\text { 2.1.1: Sight } \\
\text { 2.1.2: Hearing } \\
\text { 2.1.3: Smell } \\
\text { 2.1.4: Taste } \\
\text { 2.1.5: Touch }\end{array}$ \\
\hline & $\begin{array}{l}\text { 2.2: Faculty of internal } \\
\text { perception }\end{array}$ & $\begin{array}{l}\text { 2.2.1: Common sense } \\
\text { 2.2.2: Retentive } \\
\text { 2.2.3: Estimative } \\
\text { 2.2.4: Imaginative } \\
\text { 2.2.5: Memory }\end{array}$ \\
\hline
\end{tabular}


Table 1: Faculties of the Animal Soul

The estimative faculty, on the other hand, is one of the chief innovations of Ibn Sina's philosophical thought. According to Ibn Sina, non-sensible intentions perceived by the estimative faculty are different from sensible forms. The latter depend on the external senses to be perceived, while the former are independent of any perceiving mediums. The results of the estimative process may also vary in truth and falsity due to the inability of the estimative faculty to perceive beyond intention. Confusion is impossible for the estimative faculty, as it can only combine and separate intentions without knowing that they need to rationalise them to reach a better understanding. As a result, the Animal Soul perceives things as they are and is incapable of changing them; this reveals why the "habitual behaviour" of man is related to the estimative faculty, while "behaviour change" is only related to the rational-imagination faculty. ${ }^{9}$

Habits are colloquially referred to as a series of human actions produced by repetition. According to Ibn Sina, which specific habitual actions a man takes up depends on the elements he is exposed to. ${ }^{10}$ For this reason, Ibn Sina asserts the importance of teaching virtues to children right after weaning (two years old), ${ }^{11}$ to accommodate the formation of good habits before the ability to reason has developed (when habits become hard to change). He did not determine a particular age for this quality, as a child's milestones can only be gauged through observation and experiment. However, it is philosophically understood that the Actual Intellect can only be activated after the activation of the Habitual Intellect. If the instrument of reason (here referring to the capability of the brain to reason in a complex way) has not yet reached mat urity, then the Actual Intellect is unable to activate. Therefore, Ibn Sina believed that children at a young age might not have the capability to organise and interpret complex input and, consequently, would depend on their teachers and parents for guidance. This point relates to why Ibn Sina elucidated the importance of educating children in Qur'an, ethics, art, and literature before adolescence, ${ }^{12}$ as well as why he emphasised the importance of good character in teachers: they act as essential role models for children. ${ }^{13}$

The only faculty of the Animal Soul that has the potential to comprehend, synthesise, and analyse input is the rational-sensitive (mufakkirah) faculty. The types of input this faculty can comprehend, as stated by Ibn Sina, are as follows: 1) forms perceived through the commonsense faculty; 2) non-sensible and sensible intentions perceived through the estimative faculty; and 3) forms which were previously arranged and combined by the sensitive-imaginative faculty. These are selected, organised, and interpreted according to a meaningful objective that allows them to be completely managed by the Rational Soul. ${ }^{14}$ At this phase, the sensitive-imaginative faculty often distracts man from perceiving wisely by enabling an ability to observe things externally. 
Intellection, as viewed by Ibn Sina, is a process of acquiring knowledge through the acts of tafakkur (to think or contemplate), ta' aqul (to reason), and tadabbur (to reflect). The three faculties mentioned above represent tafakkur, while the rational-imaginative faculty denotes ta'aqul and tadabbur the condition of the Rational Soul when being activated by the Practical Intellect. Therefore, tafakkur and $t a$ ' $a q u l$ are related to perfection by the bodily faculties, while tadabbur and a part of ta'aqul are related to perfection through the actualisation of potentialities. The Rational Soul needs the body to actualise both primary and commonly-held premises, but does not need anything other than itself to reach perfection.

The first part of the Rational Soul is the Practical Intellect. This perceives particular forms and intentions judged through commonly-held premises, commonly-accepted premises, premises based on assumptions, and the tenuous results of methodic experiences (consisting of previous assumptions, which are different from the substantiated methodic experience). ${ }^{15}$ This is all structured with the help of the Theoretical Intellect. ${ }^{16}$ This produces judgments about good and evil, right and wrong, what is permissible and non-permissible, and thus defines itself as the principal movement of the human body. Particular judgments are then imprinted on the body, to be actualised by its faculties. The root cause of the Practical Intellect's intelligence is the Animal Soul's desire to produce acts based on deliberation and purposive objectives. It corresponds to the faculties of appetence through the act of provoking the passions while using the faculties of imagination and estimation to deduce plans concerning transitory things as well as human art. ${ }^{17}$ Ibn Sina stresses that the Practical Intellect needs to govern all the faculties of the soul to produce good personalities and excellent moral qualities. This brings about the meaning of those actions that are accomplished through the act of willful reasoning (al-'amal bil ilm).

The second part of the Rational Soul is the Theoretical Intellect. This perceives (or structures) universal connotational attributes ( $m a{ }^{\prime} n a$ ) that bring "unknowns" (majhulat) to a phase of "being known" (ma lum) through a process of assertion (tasdiq) and conceptualisation. They are completely abstracted from matter and determine subjects of truth, falsehood, necessity, possibility, and impossibility, which are portrayed in the form of primary premises. ${ }^{18}$ The Theoretical Intellect is divided into four:

The Material Intellect ('aql al-hayula), which denotes the condition of absolute potentiality and the incapability of the Theoretical Intellect to perceive universals. Ibn Sina compared this situation to a child who has the potentiality to write but does not have the skills to do so. ${ }^{19}$

The Habitual Intellect ('aql bi al-malakah), which denotes the actualisation 
of potentialities and is attached to the prior ability of the intellect to perceive intelligibles (in the sense of being a receptor of universals). Self-evident premises (e.g. the whole is greater than the part, or things equal to one thing are equal to another) and emanated intelligibles are presented within the Theoretical Intellect, but are subject to the prior capacity of the body to apply the premises into syllogisms, as well as to receive intelligibles. The situation is similar to a person who has the skill to write but has not yet honed that skill to the degree of possessing proper handwriting. ${ }^{20}$

The Actual Intellect ('aql bi al-fi't), which denotes the actualisation of potentialities such that they are fully activated (and fully perfected) while intelligibles are continuously imprinted on the soul. However, the intellect still needs the soul's will power to perceive wherever universals are applicable. In other words, the primary premises are ready to be used whenever needed. Ibn Sina compares this situation to a person who has the capability to choose whether to write or not, without the need to think beforehand. ${ }^{21}$

The Acquired Intellect ('aql bi al-mustafad), which denotes the condition of completeness or absoluteness in the intellect's potentiality to perceive universals, showing the continuous act of perception by the intellect. The Theoretical Intellect is united with the act (or the Rational Soul, meaning the genus of human rationality is united with the species of the human animal) in such a way that does not require attachment to the bodily faculties to reach perfection. This is analogous to the person who is skillful in art, such that they are capable of creating new methods of drawing. In education, a learner or educator who has reached this stage of intellection is known as creative, analytical, rational, critical, holistic, and divergent.

\section{The Designation Scheme and Implications of the Proposed Taxonomy}

In an educational settling, a taxonomy is used to identify learning objectives. ${ }^{22}$ It also helps teachers, administrators, professional specialists, and research workers who deal with curricular and evaluation problems. ${ }^{23}$ Learning objectives direct learner behaviour towards specific goals, with various educational instructions acting as a stimulus. However, before adequately identifying educational objectives, one needs to predict a lesson's learning outcomes and the learners' intended behaviours. For this reason, taxonomies need to be based on a guiding principle that is internally consistent, containing coherent terms that are clearly 
defined. This is in agreement with the logical classification that Ibn Sina provided in his philosophical works. In addition, metaphysical divisions accompany this classification, aligning it with the objectives of Islamic education.

Islamic classrooms provide learning experiences based on Islam's fundamentals, as embodied in the Holy Qur'an and Sunnah. Classes tend to develop faith and commitment towards basic values, developing a sense of accountability towards the All Mighty and a closer understanding of Him. Learners, as a result, tend to realise their position as a vicegerent standing before Allah. This denotes the fact that Islamic classrooms attempt to foster the ability to apply faith to every aspect of life. This also brings about the point that intended behaviours are the focus of Islamic classrooms.

Behaviour is closely related to how a learner thinks and extracts particulars from given information. Educators need to evaluate the results of class participation by determining whether the act of intellection: 1) is at the level of surface understanding - that is, merely using commonsense and estimation; 2 ) involves complexity in organising input through the act of imagination; 3 ) interprets ideas through rational thinking; 4) applies knowledge through practice; or, 5) demonstrates the ability to synthesise ideas through the process of creativity and innovation. Appropriate values will then be linked to specific "indicators" set up to specify objectives. It will depend on the creativity of educators as to whether objectives that trigger these indicators are applied following the line "simple to complex" or a combination of random choices. The "indicators" can be observed in subject-matter contents, specifying different teaching methods labelled according to Islamic educational terms. These specifications will enhance educator communication in regards to classroom objectives and evaluating procedures, as they will now focus on specific indicators for developing learner skills and abilities. This idea of relating human behaviours to educational objectives was originally developed in the taxonomy of Benjamin Bloom (1913-99). The taxonomy proposed here will apply the same approach, linking Islamic educational objectives and teaching methods to Ibn Sina's human categorisation. Bloom developed a taxonomy based on developmental phases defined by surveys, data collection, and psychological and educational analyses, both theoretical and practical. The current proposed taxonomy, however, is based on library research and philosophical analysis alone. Nevertheless, it is designed specifically for Islamic classrooms and signifies moral articulation and internal human perfection.

A taxonomy is crucial for ensuring the realisation of classroom objectives. It makes educator ideas lucid, facilitating a better understanding of different perspectives using specific terms of classification. It also helps educators to: 1) organise ideas and objectives, from less important to most important; 2) 
avoid unnecessary repetitive tasks; and 3) limit the implementation of various instructional methods and tools. Therefore, it is vital to identify the consensus among educators, administrators, educational policymakers, and researchers when defining the terms used to facilitate communication. It is also necessary to revisit the foundation of child psychology and development to ensure the suggested taxonomy is relevant.

It is hoped that the new taxonomy suggested here will support the professional development of Islamic teachers, helping them implement twenty-first-century curricula, including various teaching methods, such as flipped classrooms, project-based learning, cooperative learning, gamification, problem-based learning, design thinking, thinking-based learning, and competency-based learning. This taxonomy also attempts to eliminate volatility and uncertainty among educators adapting to new learner-centered atmospheres, helping them to nurt ure the spiritual, psychical, moral, and cognitive development of learners. This is aligned with the Malaysian Education Blueprint and National Education Philosophy, ensuring the development of a holistic child, whether intellectually, spiritually, emotionally, or physically, through a school curriculum that is able to produce citizens "who are knowledgeable and competent, who possess high moral standards, and who are responsible and capable of achieving high levels of well-being as well as being able to contribute to the harmony and betterment of the family, the society, and the nation at large." ${ }^{24,25}$

The connection between domains and sub-divisions within particular lessons and teaching methods allows teachers to focus on the development and assessment of universal values. This will ensure the building of a robust Malaysian identity that embraces moral qualities and unity (listed as the third shift in the Malaysian education system transformation) ${ }^{26}$ People will be understood and appreciated according to their individual values and skills, rather than their different beliefs, cultures, or ethnicities.

\section{An Islamic Education Taxonomy based on Ibn Sina's Theory of the Soul}

The main domains of the proposed taxonomy are classified using the types of soul suggested by Ibn Sina, namely: Vegetative, Animal, and Rational. The various bodily faculties will be subdivided according to their domains and connected to teaching methods based on their functions. The contents of an Islamic education are related to different teaching methods: tarbiyyah (to train), ta'limiyyah (to teach), ta'dibiyyah (to make behave), and tahzibiyyah (to purify). They also relate to the nature of the subject matter covered. Educators will first need to 
determine the domain they intend to teach and develop, thereby leading to the subdivisions that will specify the objectives of their classrooms. Expected learner outcomes will be identified from the functionality of the bodily faculties, as well as the degree of perfection determined by the lower and higher skills included in each faculty. However, the identified methods and subjects used as a guideline for teaching are interchangeable in order to implement cross-curricular teaching within classrooms.

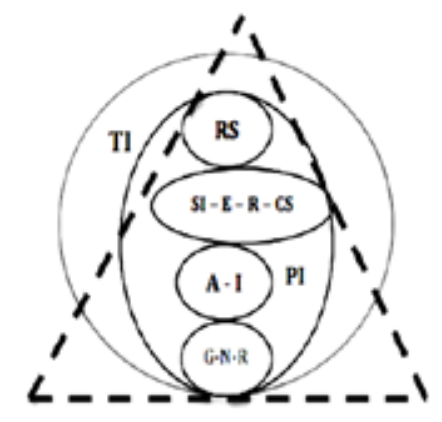

Figure 1: Taxonomy No. 1 - Classification of the Human Soul

Note: TI (Theoretical Intellect), PI (Practical Intellect), RS (Rational-Imaginative Faculty), S-E-R-CS (Sensitive-Imaginative, Estimative, Retentive, Commonsense Faculties), A-I (Appetitive, Irascible Faculties), G-N-R (Growth, Nutritive, Reproductive Faculties),

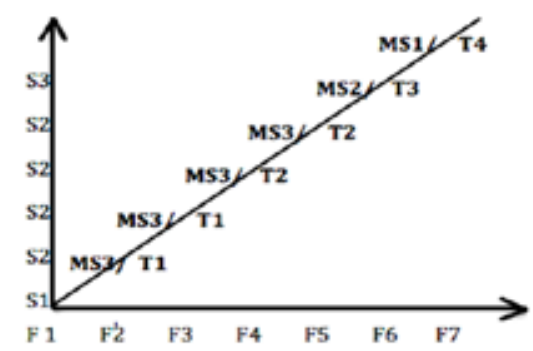

Figure 2: Taxonomy No. 2 - Classification of the Human Soul, Islamic Education Subjects, and Teaching Methods

Note: S1 - Vegetative Soul, S2 - Animal Soul, S3 - Rational Soul, F1 - Appetitive and Irascible Faculties, F2 - Commonsense Faculty, F3 - Estimative Faculty, F4 - Sensitive Imaginative 
Faculty, F5 - Rational Imaginative Faculty, F6 - Practical Faculty, F7 - Theoretical Faculty, T1 - Tarbiyyah, T2 - Ta'limiyyah, T3 - Ta'dibiyyah, T4 - Tazkiyyah, MS1 - Logic, Philosophy, Principle of Jurisprudence, MS2 - Jurisprudence, Ethics, MS3 - Other Islamic Education Subjects.

Figure 1 shows the hierarchical classification of the human soul, denoting the descending movement of universal and particular forms, and intelligible movement from the intellects towards a higher level of perfection. The hierarchy indicates the human soul comprises a series of intellects and bodily faculties. This visualises the united-attached relationship between soul and body, as pictured by Ibn Sina. The three domains of the taxonomy (Vegetative, Animal, and Rational) are classified based on the genus of man and on man as a particular species. The three circular figures denote the subdivisions of the domains, moving from the faculties that accomplish simple activities to the faculties that carry the work of complex activities. Educators should develop the lower faculties before the higher ones in order to enable learners to reach intellectual perfection in both worlds (material and immaterial). It is also permissible, however, for educators to focus on the development of certain bodily faculties throughout their lessons to create flexibility in learning. Another context that should also be considered is the relevance of objectives to learner capacity; the most effective method is to teach and determine classroom objectives based on the positions of souls, from the lowest to the highest.

Figure 2 represents the link between domains and subdivisions within the taxonomy. Specific teaching methods and subjects are connected with a straight line to show the relevance between them. The positive slope shows a soul's progression towards actuality and perfection, but only if the variables on the vertical axis (bodily faculties, referring to learner outcomes) increases along with the variable on the horizontal axis (type of soul). It also depends on whether the suggested teaching methods for certain subjects (at the plots) are implemented. The classification of the soul according to the genus is seen at the vertical axis, while the horizontal axis points to the differentia of the human soul and the subdivision of the bodily faculties. The plotted points on the graph indicated by the letter $\mathrm{T}$ are Islamic education teaching methods: T1- tarbiyyah (to train), T2 ta 'limiyyah (to educate), T3 - ta'dibiyyah (to make behave), and T4 - tazhibiyyah (to purify). The letters located beside the Ts are Islamic educational subjects. These are classified by nature (subject matter) and linked to different teaching methods. The letter S, which refers to the domains of the taxonomy, helps educators determine the type of soul they are attempting to develop. F depicts the outcome of the learners, as well as the specified intended behaviours that 
educators will need to observe to ensure that classroom objectives are realised. It also identifies where development should be observed in learners. The letter $\mathrm{T}$ offers teaching methods that should be used in the particular setting of the classroom, while the letters MS illustrate the main subjects of lesson plans. The latter helps educators seek relevant topics to be included in the objectives of their classrooms.

\section{Conclusion}

According to Ibn Sina, man can dominate his animalistic desires and actions by allowing the Rational Soul to govern his lower souls. This will allow him to become the Perfect Man (insan al-kamil), a position that places him closer to the Divine. In the view of Ibn Sina, this can only be accomplished through the act of intellection. Rationality is a manifestation of man's intellect through which he seeks ultimate perfection and happiness. Ibn Sina's theory of the soul is the most convenient theory for the designation of a new taxonomy in the field of Islamic education. This is due to its logical-metaphysical classification, which ensures an internally consistent structure for developing an educational taxonomy. It will assist educators in determining appropriate objectives for their classrooms and avoid the act of over-emphasising educational objectives at the expense of twenty-first-century demands.

\section{Notes}

* Nurul Ain Norman is a Research Fellow at the International Institute of Advanced Islamic Studies (IAIS) Malaysia. Email: ainnorman@iais.org.my.

1. Mohammad Hashim Kamali, 'Perspective on Thinking,' New Straits Times, 12 June 2017, https://www.nst.com.my/opinion/columnists/2017/06/248090/ quranic-perspective-thinking.

2. On al-Farabi's theory of the soul, see Osman Bakar, Classification of Knowledge in Islam (Kuala Lumpur: ISTAC, 2006), 48-64, 108-9.

3. Fazlur Rahman, The Philosophy of Mulla Sadra (Albany: State University of New York Press, 1975), 3, 13.

4. Nurul Ain Norman, 'Islamic Philosophy for Soul Development in Early Childhood: A Model based on Ibn Sina's Theory of Soul,' Unpublished PhD thesis, University of Malaya (2020), 128-9.

5. Ibid., 119-10.

6. Jon McGinnis and David C. Reisman, Classical Arabic Philosophy (translation of Kitab al-Shifa': al-Nafs) (Cambridge: Hackett Publishing Company Inc., 
2007), 205-6.

7. Ibid., 25.

8. Al-Husayn ibn Abdallah Ibn Sina, al-Qanun al-Tib (Beirut: Darul Kitab alIlmiyah. n.d.), 160-7.

9. Ibid., 427.

10. Adlina Ariffin, 'A Comparative Analysis of Ibn Sina and Al-Ghazali: Their Philosophical Underpinnings and Contributions toward Muslim Education,' paper presented at World Congress for Islamic History and Civilisation (WOCIHAC), University Malaya (2011), 6.

11. Al-Husayn ibn Abdallah Ibn Sina, Ibn Sina wa Tadbir al-Manzil, trans. Muhammad Najmi Zanjani (Tehran: Mujtama' Nashir Kitab, 1319), 43. In Norman, 'Islamic Philosophy', 203.

12. Al-Husayn ibn Abdallah Ibn Sina, Kitab al-Siyasiyah, ed. Ali Md. Isbar (Beirut: Dar al-Bidayah, n.d.), 84.

13. Ibn Sina, Ibn Sina wa Tadbir al-Manzil, 87.

14. Al-Husayn ibn Abdallah Ibn Sina, Nafs Shifa', trans. Md. Husayn Nayeji (Qom: Intisharat Amoozeshi wa Pajooheshi Imam Khomeini, 1388), 438.

15. Ginnis and Reisman, Classical Arabic Philosophy,187.

16. See Ibid.,187; Ibn Sina, Nafs Shifa', 497.

17. Ginnis and Reisman, Classical Arabic Philosophy, 187; Ibn Sina, Nafs Shifa', 497.

18. See Ginnis and Reisman, Classical Arabic Philosophy, 187; Ibn Sina, Nafs Shifa', 497.

19. Peter Heath, Allegory and Philosophy in Avicenna (Pittsburgh: University of Pennsylvania Press, 1992), 65; Fazlur Rahman, Avicenna 's Psychology (Oxford: Oxford University Press, 1952), 33-4.

20. Al-Husayn ibn Abdallah Ibn Sina, Kitab al-Najah fi al-Hikmah al-Mantiqiyah wa al-Tabi'iyah wa Ilahiyah, ed. Majid Fakhry (Beirut: Manshoorat Darul Ufuq al-Jadidah, 1982), 205.

21. Ibid., 205.

22. Benjamin S. Bloom et. al, Taxonomy of Educational Objectives (London: David McKay Company Inc., 1956), 1.

23. Ibid.

24. Malaysia Education Blueprint 2013-2025 (Preschool to Post-Secondary Education) (Putrajaya: Kementerian Pendidikan Malaysia, 2013), 4. Available at: www.moe.gov.my.

25. Ibid.

26. See Shift 3 (Develop Values-Driven Malaysians) in Eleven Shift to Transform the System, Malaysian Education Blueprint 2013-2025, 13.

\section{Bibliography}

Ariffin, Adlina. 'A Comparative Analysis of Ibn Sina and Al-Ghazali: Their Philosophical Underpinnings and Contributions toward Muslim Education,' paper presented at World Congress for Islamic History and Civilisation (WOCIHAC), University Malaya (2011). 
Bakar, Osman. Classification of Knowledge in Islam. Kuala Lumpur: ISTAC, 2006.

Bloom, Benjamin S., Max D. Engelhart, Edward J. Furst, Walker H. Hill, and David R. Krathwohl. Taxonomy of Educational Objectives. London: David McKay Company Inc., 1956.

Heath, Peter. Allegory and Philosophy in Avicenna. Pittsburgh: University of Pennsylvania Press, 1992.

Ibn Sina, al-Husayn ibn Abdallah. Ibn Sina wa Tadbir al-Manzil. Translated by Muhammad Najmi Zanjani. Tehran: Mujtama' Nashir Kitab, 1319.

. Nafs Shifa'. Translated by Md. Husayn Nayeji. Qom: Intisharat Amoozeshi wa Pajooheshi Imam Khomeini, 1388.

Kitab al-Najah fi al-Hikmah al-Mantiqiyah wa al- Tabi'iyah wa Ilahiyah. Edited by Majid Fakhry. Beirut: Manshoorat Darul Ufuq al-Jadidah, 1982. al-Qanun al-Tibb. Beirut: Darul Kitab al- Ilmiyah, n.d.

Kamali, Mohammad Hashim. 'Perspective on Thinking'. New Straits Times, 12 June, 2017. https://www.nst.com.my/opinion/columnists/2017/06/248090/quranicperspective-thinking.

Malaysia Education Blueprint 2013-2025 (Preschool to Post-Secondary Education). Putrajaya: Kementerian Pendidikan Malaysia, 2013. Available at: www.moe. gov.my.

McGinnis, Jon and David C. Reisman. Classical Arabic Philosophy (translation of Kitab al-Shifa': al-Nafs). Cambridge: Hackett Publishing Company Inc., 2007.

Norman, Nurul Ain. 'Islamic Philosophy for Soul Development in Early Childhood: A Model based on Ibn Sina's Theory of Soul.' Unpublished PhD dissertation, University Malaya, 2020.

Rahman, Fazlur. The Philosophy of Mulla Sadra. Albany: State University of New York Press, 1975. 